\title{
Comparison of the Effect of Aerosols of Saline and Mineral Water on the Tracheal Epithelium
}

\author{
V. KONRÁDOVÁ ${ }^{1}$, L. VAJNER ${ }^{1}$, J. UHLÍK $^{1}$, J. ZOCOVÁ ${ }^{2}$ \\ ${ }^{1}$ Institute of Histology and Embryology, $2^{\text {nd }}$ Medical Faculty and ${ }^{2}$ Department of Applied Mathematics \\ and Computer Science, Faculty of Science, Charles University, Prague, Czech Republic
}

Received June 27, 2002

Accepted March 25, 2003

\begin{abstract}
Konrádová V., L. Vajner, J. Uhlík, J. Zocová: Comparison of the Effect of Aerosols of Saline and Mineral Water on the Tracheal Epithelium. Acta Vet. Brno 2003, 72: 151-156.

Ultrastructure of the airway epithelium and character of glycoconjugates produced by secretory cells were studied after 10-min inhalations of saline and mineral water aerosols. Methods of electron microscopy and conventional and lectin histochemistry were used. The results were evaluated quantitatively. The target cells for the function of both aerosols were the goblet cells. These cells were overstimulated and the mechanism of mucus evacuation was accelerated. The exhausted goblet cells mostly took part in further secretory cycles. The cells not entirely filled with secretory granules prevailed in the epithelium. Massive differentiation of new secretory elements caused changes in the secretory cells' distribution. Of the two aerosols, only mineral water induced significant changes in the composition of glycoconjugates in the secretion of goblet cells. Due to administration of saline, the ciliated cells were less damaged. The percentage of altered cilia was significantly lower compared with that after mineral water inhalation. Morphological signs of impaired self-cleaning ability of the airway epithelium were discovered only after mineral water inhalation. From the morphological point of view, administration of saline aerosol is less harmful compared with that of mineral water.
\end{abstract}

Airways, ciliated cells, goblet cells, electron microscopy, lectin histochemistry, inhalation

In our preceding study, we demonstrated that single 10-min inhalation of mineral water aerosol overstimulated secretory elements in the tracheal epithelium. Changes in the character of secreted glycoconjugates (GCs) were also recorded (Konrádová et al. 2001). We therefore decided to investigate also the effect of inhalation of saline aerosol and to compare it with that produced in the epithelium by inhalation of mineral water.

\section{Materials and Methods}

In our experiments, 19 SPF New Zealand White rabbits (body weight 1,500-3,000 g, Charles River Deutschland, Sulzfeld, Germany) were used. Seven of them served as untreated controls. The remaining animals were placed successively for $10 \mathrm{~min}$ into a plastic cage connected with the inhalation device PARI Master and nebuliser PARI LL (Pari GmbH, Starnberg, Germany, medium diameter of produced droplets $3.1 \mathrm{~m} \mathrm{~m}$, total output $0.6 \mathrm{~g} / \mathrm{min}$ ). Six rabbits inhaled an aerosol of saline; another six rabbits were treated with an aerosol of natural hypertonic iodinated spring water (osmolarity $331 \mathrm{mOsm}, \mathrm{pH} 6.48$ ). The chemical composition of the spring water was specified in our previous study (Konrádová et al. 2001). The material for electron microscopic and histochemical examinations was collected under general anaesthesia immediately post exposure.

Tiny fragments of the tracheal mucous membrane were fixed for 90 min with $5 \%$ glutaraldehyde in cacodylate buffer ( $\mathrm{pH} 7.2)$ and then for 60 min with $2 \% \mathrm{OsO}_{4}$ in cacodylate buffer $(\mathrm{pH} 7.4)$, dehydrated in graded series of alcohol and embedded in a Durcupan-Epon mixture. Ultrathin sections were prepared on Ultrotome Nova (LKB, Broma, Sweden), contrasted with uranyl acetate and lead citrate and examined under the JEM $100 \mathrm{C}$ electron microscope (Jeol, Tokyo, Japan).

In the formalin-fixed and paraffin-embedded material, the methods of conventional histochemistry (Alcian Blue $/ \mathrm{AB} / \mathrm{pH} 2.5-\mathrm{PAS}$ and $\mathrm{AB} \mathrm{pH}$ 1.0) as well as of in situ lectin histochemistry, described in detail in our previous study (V ajner et al. 2000), were employed. Maackia amurensis agglutinin MAA, Sambucus nigra agglutinin SNA 
(Boehringer, Mannheim, Germany), and Tritrichomonas mobilensis lectin TML (Calbiochem, La Jolla, USA) were used. Combination of these histochemical methods recognises neutral, acid sulphated and acid sialylated [a(2-3), a(2-6) and total] GCs in the goblet cells' secretion.

The ciliary border and the functional state of the goblet cells were evaluated quantitatively. For the quantitative evaluation, the same methods as in our previous experiments were used (Konrádová et al. 2001). In controls and after inhalations of saline and of mineral water, $1,058 \mathrm{~m} \mathrm{~m}^{2}, 1,359.25 \mathrm{~m} \mathrm{~m}^{2}$ and 2,057 m m $\mathrm{m}^{2}$ of ciliary border with $10,252,9,028$ and 13,040 kinocilia were evaluated, respectively. In those experimental groups also a total of 186, 363 and 567 goblet cells using electron microscopy and 398, 325 and 379 goblet cells in histochemical studies were examined, respectively.

\section{Results}

\section{Control Rabbits}

In the tracheae of control rabbits, pseudostratified columnar ciliated epithelium composed of differentiated ciliated and goblet cells, basal cells and individual differentiating elements was revealed. In the epithelium, the ciliated cells were the most numerous, goblet cells, mostly filled with mucus, were mostly scattered as isolated elements among the ciliated ones. Only $6 \pm 3 \%$ of them formed tiny groups (Table 1 ). Gradual evacuation of individual apical mucous granules was noticed in 3\% of secretory elements. The conventional histochemistry revealed the dominance of goblet cells containing acid GCs. The proportion of sulphated GCs, detected by classic histochemistry, and the total percentage of goblet cells containing sialylated GCs visualised by the reactions with the lectins were given in Table 1. Above the epithelium, regular ciliary border was developed. Per $1 \mathrm{~m} \mathrm{~m}^{2}, 9.7 \pm 0.3$ cilia were found. $98.8 \pm 0.1 \%$ of cilia were intact. The proportions of pathological, degenerating and malformed cilia are given in Table 1.

10 -min inhalation of saline

After inhalation of saline aerosol, an altered pseudostratified ciliated epithelium with narrow intercellular spaces and intact apical junctional complexes was encountered in the tracheae (Plate V, Fig. 1). Goblet cells were still found as isolated elements among the ciliated cells, but $311 \%$ of them were concentrated to form small intraepithelial mucous glands (Table 1). Only $9 \%$ of goblet cells were distended with typical large light coalescent mucous granules.

Cells not entirely filled with mucus prevailed in the epithelium (Plate V, Figs 2-4). On their apical portions, short irregular microvilli were developed (Fig. 2). In their cytoplasm, only a few small, highly electron dense granules (Fig. 2) or more numerous granules of various electron density were revealed (Fig. 3). In some cells, isolated medium-sized granules with light fibrogranular matrix were discovered (Fig. 4). Also cells rich in small typical mucous granules separated by voluminous cytoplasmic septa were encountered.

Secretion was evacuated from mucus-filled cells as well as from cells containing only isolated secretory granules. In cells distended with mucus, not only the evacuation of apical mucous granules, but also the detachment of whole packets of granules and also chain fusion of the adjacent mucous granules' membranes followed by instantaneous evacuation of the whole mucus load, were noticed.

Completely exhausted goblet cells with highly electron dense cytoplasm represented $4 \%$ of secretory elements in the epithelium (Plate VI, Fig. 5).

No significant changes in the proportion of goblet cells containing individual types of GCs were encountered using both conventional and lectin histochemistry compared with controls (Table 1).

In contrast to the goblet cells, the ciliated cells were less damaged. Slight signs of apical blebbing were revealed on their apical portions (Plate VI, Fig. 6). Isolated small cytoplasmic blebs did not contain axonemes of degenerating kinocilia. In the deeper portions of ciliated 
cells' cytoplasm, a slight increase in the number of small vacuoles, secondary lysosomes, dilatation of the cisternae of granular endoplasmic reticulum and Golgi complex and signs of mitochondria alteration were encountered (Plate VI, Fig. 7). Isolated differentiating ciliated cells were also recorded.

The ciliary border was slightly impaired. The mean number of cilia per $1 \mathrm{~m} \mathrm{~m}^{2}$ was $6.6 \pm 0.4$. The altered cilia amounted only to $3.2 \pm 1.2 \%$. The proportions of the individual types of altered kinocilia were given in Table 1 . In the area of slightly altered ciliary border, only isolated clumps of condensed mucus were revealed.

\section{0 -min inhalation of mineral water}

Tracheae of the rabbits exposed to mineral water aerosol were lined with a slightly altered pseudostratified ciliated epithelium where $34 \pm 1 \%$ of the secretory elements were arranged in groups. $9 \%$ of goblet cells were distended with mucus load; the completely exhausted elements amounted to $4 \%$. The cells containing only a few secretory granules were the most numerous in the epithelium. Secretion was released both from mucus-filled cells and from cells where only isolated secretory granules were developed.

Compared with controls, significant decrease in number of goblet cells containing acid sulphated GCs was detected using methods of conventional histochemistry. Lectin histochemistry revealed slight, but significant increase in total number of goblet cells containing sialylated GCs (Table 1).

On the apical portions of the ciliated cells, small cytoplasmic protrusions were noticed. In their cytoplasm, signs of mild alteration were revealed, too.

Above the epithelium, $6.3 \pm 0.4 / \mathrm{m} \mathrm{m}^{2}$ kinocilia were counted. The altered elements amounted to $4.2 \pm 0.7 \%$. The distribution of individual types of altered cilia is given in Table 1. In the area among the kinocilia, clumps or layers of inspissated secretion were frequently observed (Plate VI, Fig. 8).

\section{Discussion}

To our knowledge, the effect of inhalation of saline or mineral water on the ultrastructure of the airway epithelium and on the chemical composition of the goblet cells' secretion was not studied. Many years ago, a positive effect of repeated inhalations of mineral water on the self-cleaning ability of the upper respiratory tract was demonstrated (Vaskivskij 1968).

The target cells for the function of both aerosols were the goblet cells. Due to the 10-min inhalations of both saline and mineral water, about $90 \%$ of goblet cells were stimulated to discharge their mucus. Also the mechanism of mucus evacuation was accelerated. Signs of an apocrine type of secretion and of compound exocytosis were encountered (Specian and Neutra 1980; Roumagnac and Laboisse 1987; Specian and Oliver 1991; Konrádová et al. 1996; Newman et al. 1996). Only a few exhausted secretory cells degenerated. The goblet cells mostly took part in further secretory cycles. In the epithelium, cells not entirely filled with secretory granules prevailed.

The high level of secretory cells' stimulation also induced a massive differentiation of new secretory elements (Kon rád ová et al. 1996, 1990). The differentiating goblet cells are still able to divide (Becci et al. 1978); therefore massive differentiation of new secretory elements resulted in the changes in goblet cells' distribution in the epithelium. After short inhalation of both aerosols, more than $30 \%$ of goblet cells participated in the formation of rather voluminous intraepithelial mucous glands, while in controls, less than $10 \%$ of secretory elements formed small groups in the epithelium.

In healthy control rabbits, the presence of neutral, acid sulphated and sialylated GCs, the majority of acid GCs to neutral ones, and the dominance of sulphated GCs in the secretion of the goblet cells was ascertained by both conventional and lectin-histochemistry methods. 
The proportions of total sialylated GCs revealed by two methods of lectin histochemistry did not differ significantly. These results were in accordance with those of other authors (Castells et al. 1990; Mandal and Mandal 1992; Jeffery et al. 1992).

Of the two aerosols, only mineral water induced significant changes in the composition of GCs in the secretion of the goblet cells. Percentage of neutral GCs containing goblet cells varied non-significantly, but the significant decrease in the acid sulphated GCs was accompanied by an increase of the acid sialylated ones.

Due to administration of both aerosols, the ciliated cells were less damaged compared with the goblet ones. Slight apical blebbing and mild signs of pathological alteration were noticed in the deeper portions of the ciliated cells' cytoplasm.

The alteration of the ciliated cells was reflected in the impairment of the ciliary border. Significant decrease in the mean number of kinocilia to $6.6 / \mathrm{m} \mathrm{m}^{2}$ and $6.3 / \mathrm{m} \mathrm{m}^{2}$, respectively, was accompanied by slight, but significant increase in percentage of altered cilia. Comparing the effects of the two aerosols, the average number of kinocilia $/ \mathrm{m} \mathrm{m}^{2} \mathrm{did}$ not differ significantly, but the amount of altered cilia was slightly, but significantly lower after inhalation of saline. The lower occurrence of altered kinocilia evidenced lower grade of pathological alteration of the apical portions of the ciliated cells.

After mineral water inhalation, morphological signs of impaired self-cleaning ability of the airway epithelium were discovered (Konrádová 1990; Stratmann et al. 1991; Wanner et al. 1996; Geiser et al. 1997). Layers of condensed mucus were found in the area of the slightly impaired ciliary border. Due to the inhalation of saline aerosol, the signs of local mucus flow impairment were only slight.

The changes induced in the ultrastructure of the tracheal epithelium due to the inhalations of both aerosols differed only slightly, but the effects of saline aerosol on the GCs composition, on the apical portions of the ciliated cells and on the self-cleaning ability of the epithelium were less pronounced. We arrived at the conclusion that even single 10-min inhalation of both aerosols caused significant changes in the ultrastructure of the airway epithelium but from the morphological point of view, administration of saline aerosol is less harmful compared with that of mineral water.

\section{Srovnání účinku aerosolu fyziologického roztoku a minerální vody na epitel trachey}

Ultrastruktura epitelu dýchacích cest a složení glykokonjugátů produkovaných sekrečními buňkami byly studovány po 10-minutové inhalaci aerosolu fyziologického roztoku a minerální vody. Ve studii byly užity metody elektronové mikroskopie a konvenční a lektinové histochemie. Výsledky studie byly hodnoceny statisticky. Působení obou aerosolů bylo zaměřeno zejména na pohárkové buňky. Tyto buňky byly nadměrně stimulovány a mechanizmus jejich sekrece byl urychlen. Zcela vyprázdněné pohárkové buňky se většinou zapojovaly do dalších sekrečních cyklů. Buňky, které nebyly zcela naplněny sekretem, v epitelu převažovaly. Masivní diferenciace nových sekrečních elementů způsobila následně změny $\mathrm{v}$ distribuci pohárkových buněk. Ze sledovaných aerosolů pouze aplikace aerosolu minerální vody vyvolávala významné změny ve složení glykokonjugátů v sekretu pohárkových buněk. Působením aerosolu fyziologického roztoku byly řasinkové buňky poškozeny méně. Zastoupení alterovaných řasinek bylo signifikantně nižší než po aplikaci minerální vody. Morfologické známky narušení samočisticí schopnosti epitelu dýchacích byly zaznamenány pouze po inhalaci aerosolu minerální vody. Aplikace aerosolu fyziologického roztoku poškozuje z morfologického hlediska epitel dýchacích cest méně než inhalace aerosolu minerální vody. 
No. 111300003 of Ministry of Education of the Czech Republic.

\section{References}

BECCI, P, MCDOWELL, EM, TRUMP, BF 1978: The respiratory epithelium II. J Natl Cancer Inst 61: 551-561

CASTELLS, MT, BALLESTA, J, PASTOR, LM, MADRID, JF, MARIN, JA 1990: Histochemical characterization of glycoconjugates in the epithelium of the extrapulmonary airways of several vertebrates. Histochem J 22: 24-35

GEISER, M, IMHOF, V, SIEGENTHALER, W, GRUNDER, R, GEHR, P 1997: Ultrastructure of the aqueous lining layer in hamster airways. Microsc Res Tech 36: 428-437

JEFFERY, PK, GAILLARD, D, MORET, S 1992: Human airway secretory cells during development and in mature airway epithelium. Eur Respir J 5: 93-104

KONRÁDOVÁ, V, KANTA, J, ŠULOVÁ, J 1990: Effect of bronchoalveolar lavage on the ultrastructure of the tracheal epithelium in rabbits. Respiration 57: 14-20

KONRÁDOVÁ, V., UHLÍK, J, VAJNER, L, ZOCOVÁ, J 1996: Reaction of the goblet cells to the cholinergic stimulation. Acta Vet Brno 65: 175-180

KONRÁDOVÁ, V, UHLÍK, J, VAJNER, L, ZOCOVÁ, J 2001: Changes in the tracheal epithelium during 24 hours after inhalation of mineral water. Acta Vet Brno 70: 167-172

MANDAL, C, MANDAL, C 1992: Sialic acid binding lectins. Experientia 46: 433-41

NEWMAN, TM, ROBICHAUD, A, ROGERS, DF 1996: Microanatomy of secretory granule release from guinea pig tracheal goblet cells. Am J Respir Cell Mol Biol 15: 529-539

ROUMAGNAC, I, LABOISSE, C 1987: A mucus-secreting human colonic epithelial cell line responsive to cholinergic stimulation. Biol Cell 61: 65-68

SPECIAN, RD, NEUTRA, MR 1980: Mechanism of rapid mucus secretion in goblet cells stimulated by acetylcholine. J Cell Biol 85: 626-640

SPECIAN, RD, OLIVER, MG 1991: Functional biology of intestinal goblet cells. Am J Physiol 260: C183-C193

STRATMANN, U, LEHMANN, RR, STEINBACH, T, WESSLING, G 1991: Effect of sulfur dioxide inhalation on the respiratory tract of the rat. Zbl Hyg 192: 324-335

VAJNER, L, UHLÍK, J, KONRÁDOVÂ, V, ZOCOVÁ, J 2000: The effect of intravenously administered acetylcholine on the glycoconjugate composition in goblet cells of the tracheal epithelium in rabbits. Acta Vet Brno 69: 17-23

VASKIVSKYJ, M 1968: Effect of inhalation therapy with Bílina mineral water on self-cleaning ability of the mucous membrane of the upper respiratory tract (in Czech). Fysiatr Revmatol Vestn 46: 301-304

WANNER, A, SALATHÉ, M, O'RIORDAN, TG 1996: Mucociliary clearance in the airways. Am J Respir Crit Care Med 154: 1868-1902 
Plate V

Konrádová V. et al.: Comparison... pp. 151-156

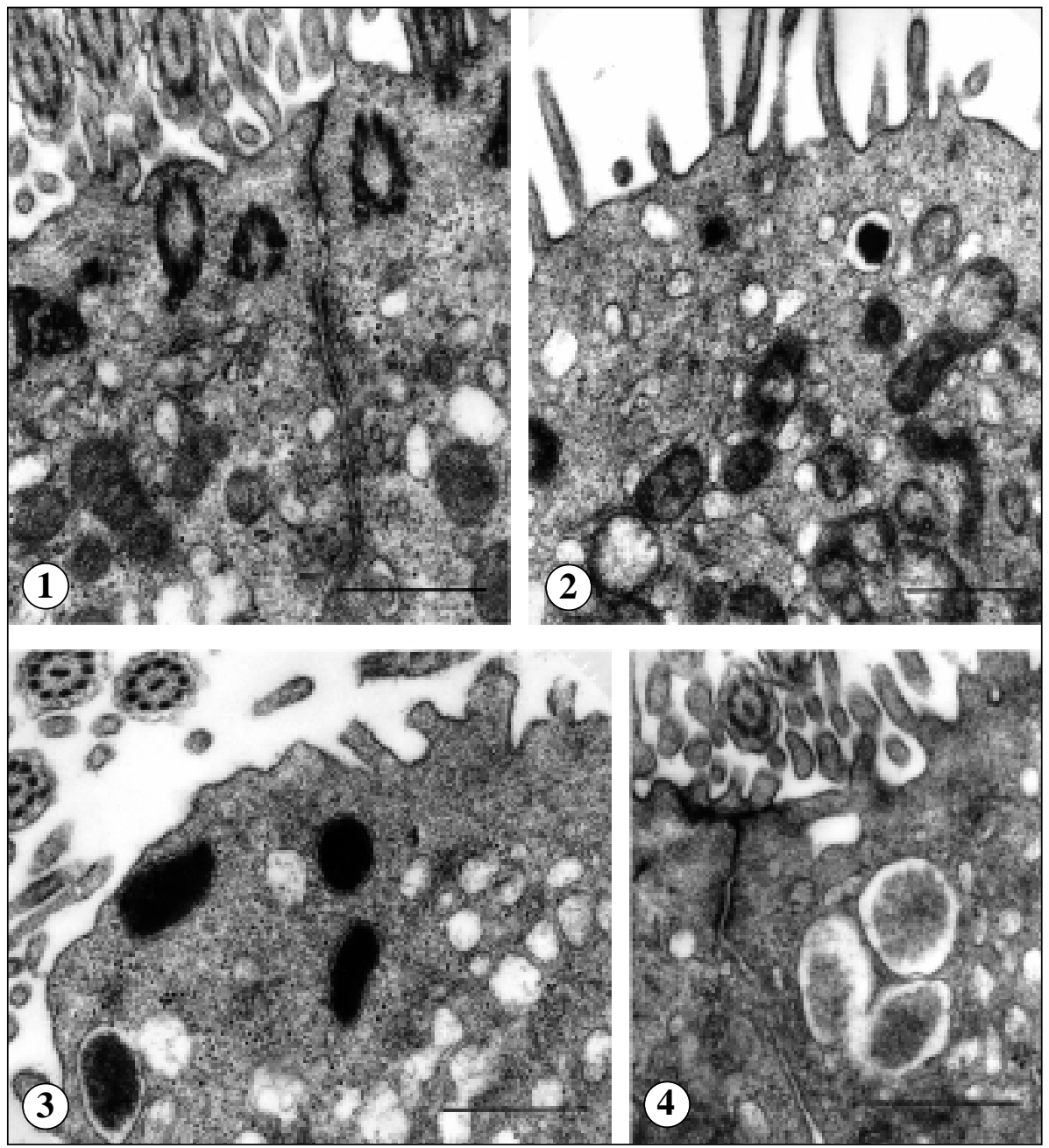

Fig. 1: Intact junctional complex in the apical portion of the epithelium. Numerous tiny vacuoles situated in the cortical portion of the ciliated cell's cytoplasm. Rabbit tracheal epithelium after inhalation of saline aerosol. Bar represents $0.5 \mathrm{~m} \mathrm{~m}$.

Fig. 2: Isolated tiny secretory granules containing electron dense material in the apical portion of cell equipped with numerous microvilli. Rabbit tracheal epithelium after inhalation of saline aerosol. Bar represents $0.5 \mathrm{~m} \mathrm{~m}$.

Fig. 3: Medium-sized granules with highly electron dense content in the apical portion of secretory cell.

Rabbit tracheal epithelium after inhalation of saline aerosol. Bar represents $0.5 \mathrm{~m} \mathrm{~m}$.

Fig. 4: Cluster of medium-sized granules with light fibrogranular matrix in the apical portion of secretory cell. Rabbit tracheal epithelium after inhalation of saline aerosol. Bar represents $0.5 \mathrm{~m} \mathrm{~m}$. 


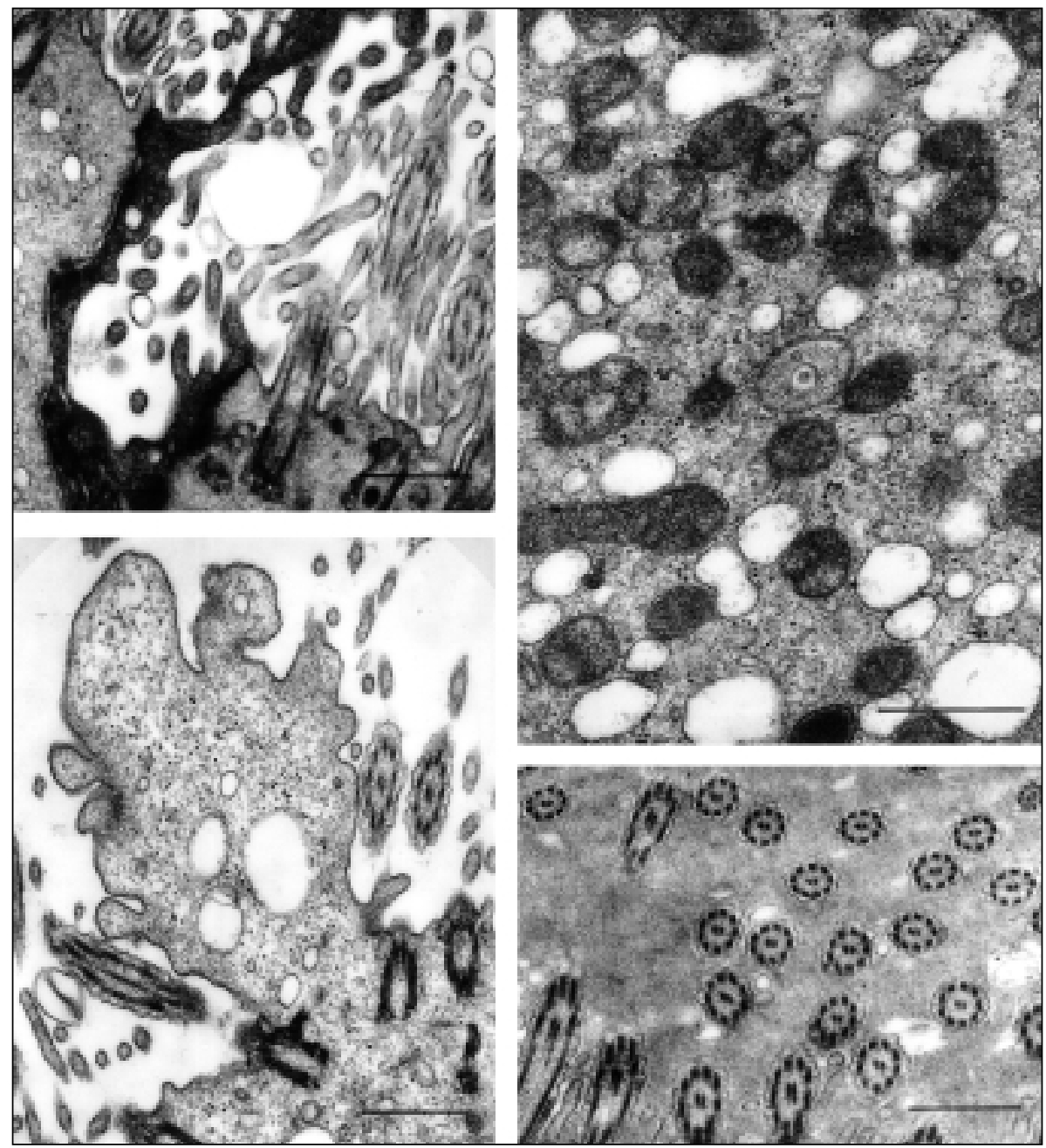

Fig. 5: Rim of highly condensed cytoplasm of an exhausted degenerated goblet cell in the apical portion of the epithelium. Rabbit tracheal epithelium after inhalation of saline aerosol. Bar represents $0.5 \mathrm{~m} \mathrm{~m}$.

Fig. 6: Small cytoplasmic bleb on the apical portion of ciliated cell. Rabbit tracheal epithelium after inhalation of saline aerosol. Bar represents $0.5 \mathrm{~m} \mathrm{~m}$.

Fig. 7. Tiny vacuoles and lysosome in the cytoplasm of slightly altered ciliated cell. Rabbit tracheal epithelium after inhalation of saline aerosol. Bar represents $0.5 \mathrm{~m} \mathrm{~m}$.

Fig. 8: Clumps of inspissated mucus among free kinocilia. Rabbit tracheal epithelium after inhalation of mineral water aerosol. Bar represents $0.5 \mathrm{~m} \mathrm{~m}$. 